УДК 615.014:582.929.4

DOI https://doi.org/10.11603/2312-0967.2021.1.11936

\title{
ХРОМАТОГРАФІЧНИЙ АНАЛІЗ ЕФІРНИХ ОЛІЙ ІЗ ТРАВИ МОНАРДИ ЛИМОННОЇ РІЗНИХ ФАЗ ВЕГЕТАЦІї
}

\author{
М. І. Шанайда ${ }^{1}$, Л. В. Свиденко ${ }^{2}$ Н. В. Гвоздик ${ }^{1}$ Н. І. Гудзь ${ }^{3}$ \\ Тернопільський національний медичний університет імені І. Я. Горбачевського \\ мОЗ України ${ }^{1}$ \\ Сектор мобілізації та збереження рослинних ресурсів Інституту рису НАAH ${ }^{2}$ \\ Львівський національний медичний університет імені Данила Галицького \\ shanayda@tdmu.edu.ua
}

\section{ІНФОРМАЦІЯ}

Надійшла до редакції / Received: 12.01.2021

Після доопрацювання / Revised: 15.01.2021

Прийнято до друку / Accepted:

20.01.2021

\section{Ключові слова:}

Monarda citriodora;

есрірна олія;

газова хроматограсрія;

тонкошарова хроматограсрія;

тимол;

карвакрол;

хемотип.

\begin{abstract}
АНОТАЦІЯ
Мета роботи. Хроматографрічний аналіз ефрірних олій монарди лимонної (Monarda citriodora Cerv. ex Lag, родина Lamiaceae Martinov), отриманих із трави рослини в різні фрази вегетації.

Матеріали і методи. Матеріалом для досліджень була трава M. citriodora, яку заготовляли на дослідних ділянках у Херсонській області на початку цвітіння та у період масового цвітіння рослин. Ефірну олію отримували методом гідродистиляції. Аналіз її компонентного складу проводили методом газової хроматограсрії з мас-спектрометричним детектуванням (ГX/ МC). Для отримання «хроматографрічних відбитків» компонентів ефірної олії використовували метод тонкошарової хроматографії (ТШХ).

Результати й обговорення. На основі ГХ/МС аналізу вивчено компонентний склад ефрірних олій сировини M. citriodora. Всього в ефрірній олії з трави рослини при ії̈ заготівлі на початку цвітіння ідентифіковано 28 компонентів, під час масового цвітіння - 27. В обох ефірних оліях домінували ароматичні монотерпеноїди тимол і карвакрол. Проведення заготівлі сировини M. citriodora у фразу масового цвітіння визначено більш перспективним 3 огляду на вищий сумарний вміст в ефрірній олії тимолу й карвакролу (84,07 \%) порівняно з початком цвітіння (75,09%). Запропоновано застосувати ТШХаналіз есрірної олії з трави досліджуваної рослини, заготовленої під час масового цвітіння, як експрес-метод її ідентифрікації.

Висновки. Визначено компонентний склад та специфічні особливості ефірних олій сировини М. citriodora заготовленої в Херсонській області (Україна) у дві різні фрази вегетації, на основі чого їх віднесено до тимоловокарвакролового хемотипу. У перспективі визначено доцільним вивчення потенціалу фармакологічної активності ефрірної олії рослини.
\end{abstract}

Вступ. В останні роки на світовому фрармацевтичному ринку збільшується попит на лікарські засоби з компонентами природного походження, що можна пояснити їхньою ефективність, безпечністю й економічною доступністю. Для визначення мож- ливості використання сировини неофіцинальних видів рослин у виробництві лікарських засобів рослинного походження необхідно провести її фрітохімічне дослідження, насамперед стосовно вмісту сполук вторинного синтезу.

ISSN 2312-0967. Pharmaceutical review. 2021. № 1 
Важливою групою біологічно активних речовин рослин є есрірні олії - багатокомпонентні суміші летких сполук, серед яких переважають похідні ізопрену $[1,2]$. У зв'язку із значним розповсюдженням проблеми антибіотикорезистентності патогенних мікроорганізмів, у наукових публікаціях активно обговорюють перспективу використання ефрірних олій рослин у складі антимікробних засобів [3-7]. Дослідження антиоксидантних властивостей ефірних олій та рослинних екстрактів також набуває особливого значення у фармації та косметології у зв'язку з виявленням токсичного впливу синтетичних консервантів $[1,8,9]$. Компонентний склад ефірних олій рослин вивчають методом газової хроматографії 3 масспектрометричним детектуванням (ГХ/МС) [10]. Застосування тонкошарової хроматограсіії (TШX) як простого й зручного методу ідентифікації домінуючих біологічно активних речовин у сировині рослин та фрітосубстанціях на їхній основі дає змогу також отримати їхні «хроматографрічні відбитки» [11].

Рід Монарда (Monarda L., родина Lamiaceae Martinov) включає 20 видів ефіроолійних трав'янистих рослин, які походять із Північної Америки. Індіанці відносили їх до категорії найбільш цінних «священних рослин», які широко використовували в лікуванні застуди, лихоманки, для промивання ран тощо [9, 12]. В останні десятиліття окремі види цього роду (M. didyma L., M. fistulosa L., M. citriodora Cerv. ex Lag., M. punctata L.) поступово поширюються в Європі переважно як декоративні рослини. Водночас їхня сировина має значний лікувальний потенціал $[12,13]$.

Попри багатовікове використання надземної частини видів роду Monarda у народній медицині північноамериканського континенту й наявності окремих експериментальних даних стосовно їхнього хімічного складу і різнопланової біологічної активності, види цього роду досі залишаються неофріцинальними. Найбільш вивченими з точки зору хімічного складу й біологічних властивостей $є$ M. didyma та M. fistulosa $[4,9,12]$. Проведений аналіз наявних наукових джерел вказує на обмеженість фрітохімічного вивчення монарди лимонної (Monarda citriodora). Зокрема, лише шість оригінальних статей було виявлено в авторитетній міжнародній базі PubMed (станом на 10 січня 2021 р.) після введення для пошуку слів «Monarda citriodora». 3 них лише дві публікації стосувались аналізу складу й активності ефрірної олії цього виду [14, 15], тоді як в інших було наведено результати досліджень грибкових ендоорітів рослини, особливостей її культивування тощо. Вважаємо, що значної уваги заслуговує ефрірна олія M. citriodora - як з точки зору визначення їі компонентного складу залежно від фрази вегетації, так і встановлення хемотипових особливостей.

Мета роботи - хроматографрічний аналіз ефрірних олій монарди лимонної (M. citriodora), отриманих із трави рослини у дві різні фрази вегетації.
Матеріали і методи. Матеріалом для досліджень була трава M. citriodora, яку заготовляли на дослідних ділянках сектора мобілізації та збереження рослинних ресурсів Інституту рису НААН (смт. Плодове, Херсонська обл.) у дві фрази вегетації: початку цвітіння і масового цвітіння. Ефрірну олію отримували методом гідродистиляції за фрармакопейною методикою 3 використанням апарата Клевенджера [10].

Компонентний склад ефірної олії аналізували методом ГX/MC із використанням хроматографра Agilent Technologies 6890 із мас-спектрометричним детектором 5973. Хроматографрічна колонка - капілярна DB-5 (30 м × 0,25 мм × 0,25 мкм); швидкість подачі газу-носію гелію - 1,2 мл/хв; програмування температури - у діапазоні 50-300 C; загальний час хроматографрування - 35 хв. Для ідентифрікації компонентів використовували бібліотеку мас-спектрів NIST05 і WILEY 2007.

Для отримання «хроматограсрічних відбитків» складових ефрірної олії та ідентифікації її домінуючого компоненту використовували метод ТШХ. Для хроматографрування застосовували ТШХ-пластини розміром 20x10 см із силікагелем $\mathrm{F}_{254}$ (Merck, Darmstadt, Germany); рухома фраза: толуол - етилацетат (95:5). Ефірну олію розчиняли в метиленхлориді. Дериватизацію проводили анісового альдегіду розчином, після чого пластинки впродовж 5-7 хв нагрівали за температури $100-105^{\circ} \mathrm{C}$ і відразу переглядали при денному світлі.

Результати й обговорення. На основі проведеного ГХ/MC аналізу визначено компонентний склад eqрірних олій M. citriodora, отриманих із трави рослини в різні фрази вегетації (табл. 1, рис. 1, 2). В ефрірній олії сировини рослини, заготовленої на початку цвітіння, ідентифріковано 28 компонентів, тоді як у фразу масового цвітіння - 27.

За даними таблиці 1, домінуючими компонентами еорірних олій M. citriodora обох фраз вегетації були тимол, карвакрол, метилкарвакрол, п-цимен і y-терпінен (рис. 3,4 ), які містились у них в різних співвідношеннях. У цілому, в обох ефрірних оліях кисневмісні монотерпеноїди переважали над безкисневими сполуками. Сесквітерпеноїди ( $\beta$-каріофілен, гермакрен D, $\delta$-кадинен та ін.) виявлено у слідових кількостях або вони взагалі були відсутні. Сполуки нетерпенової природи (1-октен-3-ол, октанон-3, октанол-3, октаналь, децилацетат, 2-6-диметокси-ацетофенон) знайдено у мінорних кількостях, що досить позитивно характеризує досліджувані ефрірні олії.

Як відомо, домінуючі компоненти ефірних олій надають їм характерного аромату, а також унікальних біологічних властивостей [2]. Ароматична структура виявлених основних компонентів досліджуваних есрірних олій M. citriodora - тимолу, карвакролу, метилкарвакрол і п-цимену - дає змогу припустити їхній значний терапевтичний потенціал. Як видно з таблиці 1, сумарний вміст у ефрірній олії таких компонентів-лі-

ISSN 2312-0967. Фармацевтичний часопис. 2021. № 1 
Фітохімічні дослідження Phytochemical researches

Таблиця 1

Компонентний склад ефрірних олій M. citriodora різних фраз вегетації рослин

\begin{tabular}{|c|c|c|c|}
\hline \multirow{2}{*}{ Компонент } & \multirow{2}{*}{$\begin{array}{c}\text { Час утримання, } \\
\text { хв }\end{array}$} & \multicolumn{2}{|c|}{$\begin{array}{l}\text { Вміст компоненту } \\
\text { в есрірній олії, \% }\end{array}$} \\
\hline & & $\begin{array}{c}\text { фаза } \\
\text { початку цвітіння }\end{array}$ & $\begin{array}{c}\text { фраза } \\
\text { масового цвітіння }\end{array}$ \\
\hline$\alpha$-туйє ${ }^{x}$ & 7,38 & 0,142 & - \\
\hline 1-октен-3-ол & 9,10 & 1,782 & 2,208 \\
\hline октанон-3 & 9,26 & 0,248 & 0,180 \\
\hline мірцен $^{x}$ & 9,40 & 1,056 & 0,391 \\
\hline октанол-3 & 9,66 & 0,184 & 0,114 \\
\hline октаналь & 9,89 & 0,423 & 0,296 \\
\hline$\alpha$-среландрен ${ }^{x}$ & 10,03 & 0,115 & - \\
\hline$\alpha$-терпінен ${ }^{x}$ & 10,40 & 1,079 & 0,527 \\
\hline п-цимен ${ }^{x}$ & 10,68 & 4,401 & 3,018 \\
\hline лимонен ${ }^{x}$ & 10,83 & 0,266 & 0,134 \\
\hline 1,8-цинеол* & 10,97 & 0,118 & 0,123 \\
\hline y-терпінен ${ }^{x}$ & 11,88 & 4,289 & 1,666 \\
\hline mранс-сабіненгідрат* & 12,33 & 1,814 & 2,003 \\
\hline ліналоол ${ }^{x}$ & 13,31 & 0,470 & 0,350 \\
\hline цис-сабіненгідрат* & 13,43 & 0,106 & 0,330 \\
\hline борнеол* & 16,07 & 0,108 & 0,234 \\
\hline терпінен-4-ол & 16,29 & 0,446 & 0,732 \\
\hline$\alpha$-терпінеол* & 17,01 & 0,148 & 0,135 \\
\hline метилкарвакрол* & 18,27 & 5,582 & 2,061 \\
\hline тимол* & 20,00 & 56,665 & 71,077 \\
\hline карвакрол* & 20,19 & 18,426 & 12,992 \\
\hline ацетилтимол* & 21,14 & 0,312 & 0,122 \\
\hline 2,6-диметокси-ацетофренон & 21,25 & 0,681 & 0,283 \\
\hline карвакрилацетат* & 21,57 & 0,130 & 0,063 \\
\hline децилацетат & 22,47 & 0,076 & 0,049 \\
\hline$\beta$-каріофрілен ${ }^{x}$ & 22,85 & 0,791 & 0,751 \\
\hline гумулен ${ }^{x}$ & 23,56 & 0,044 & - \\
\hline гермакрен $\mathrm{D}^{\mathrm{x}}$ & 24,03 & 0,098 & 0,107 \\
\hline аромадендрен ${ }^{x}$ & 24,31 & - & 0,025 \\
\hline$\delta$-кадинен ${ }^{x}$ & 24,64 & - & 0,028 \\
\hline
\end{tabular}

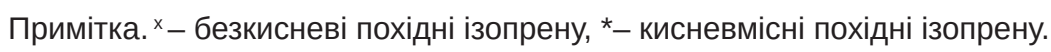

дерів, як тимол і карвакрол був значно вищим у фразу масового цвітіння рослин (84,07 \%), якщо порівняти із початком цвітіння (75,09 \%). Ці дані $€$ актуальними для аналізу можливих фрармакологічних властивостей досліджуваних еорірних олій $M$. citriodora.

Ароматичні монотерпеноїди тимол і карвакрол, які мають доведені антисептичні й антиоксидантні властивості, дослідники виявили також в ефрірних оліях інших представників родини Lamiaceae - 3 родів
Thymus, Origanum, Satureja, Monarda [2, 4, 8, 10, 1618]. Ghosh М. та співавтори [19] методом молекулярного моделювання встановили, що тимол і карвакрол, які є структурними ізомерами, мають досить подібний терапевтичний потенціал. Їхні антимікробні властивості пов'язують як із наявністю ароматичного ядра в їхній молекулі, так і гідроксильної групи [2].

Lee J. Н. та співавтори [7] встановили, що серед 79 проаналізованих ефірних олій найбільший

ISSN 2312-0967. Pharmaceutical review. 2021. № 1 


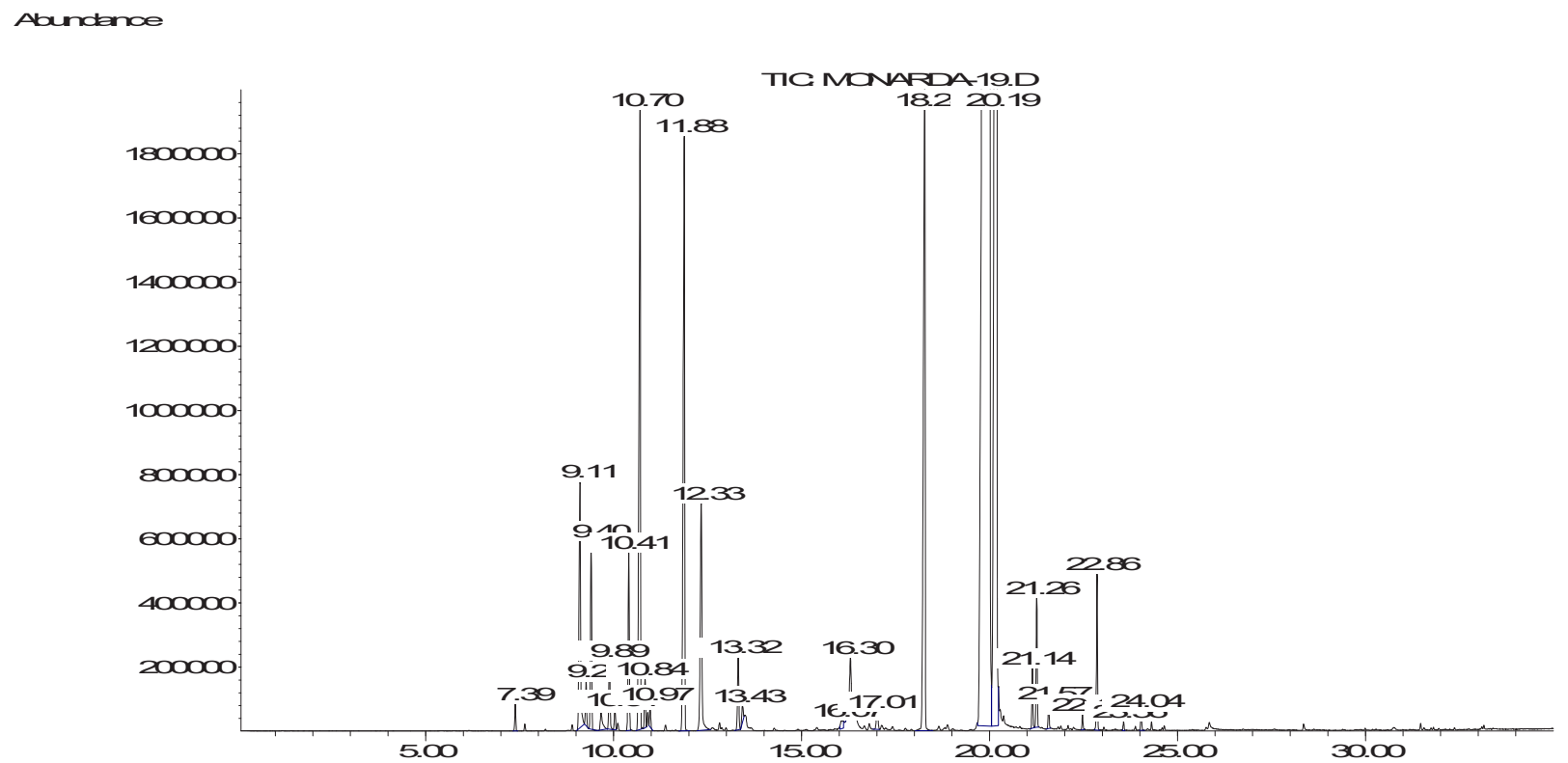

Tirre $\rightarrow$

Рис. 1. ГХ/MC хроматограма ефрірної олії M. citriodora (фраза початку цвітіння рослин).

Abundance

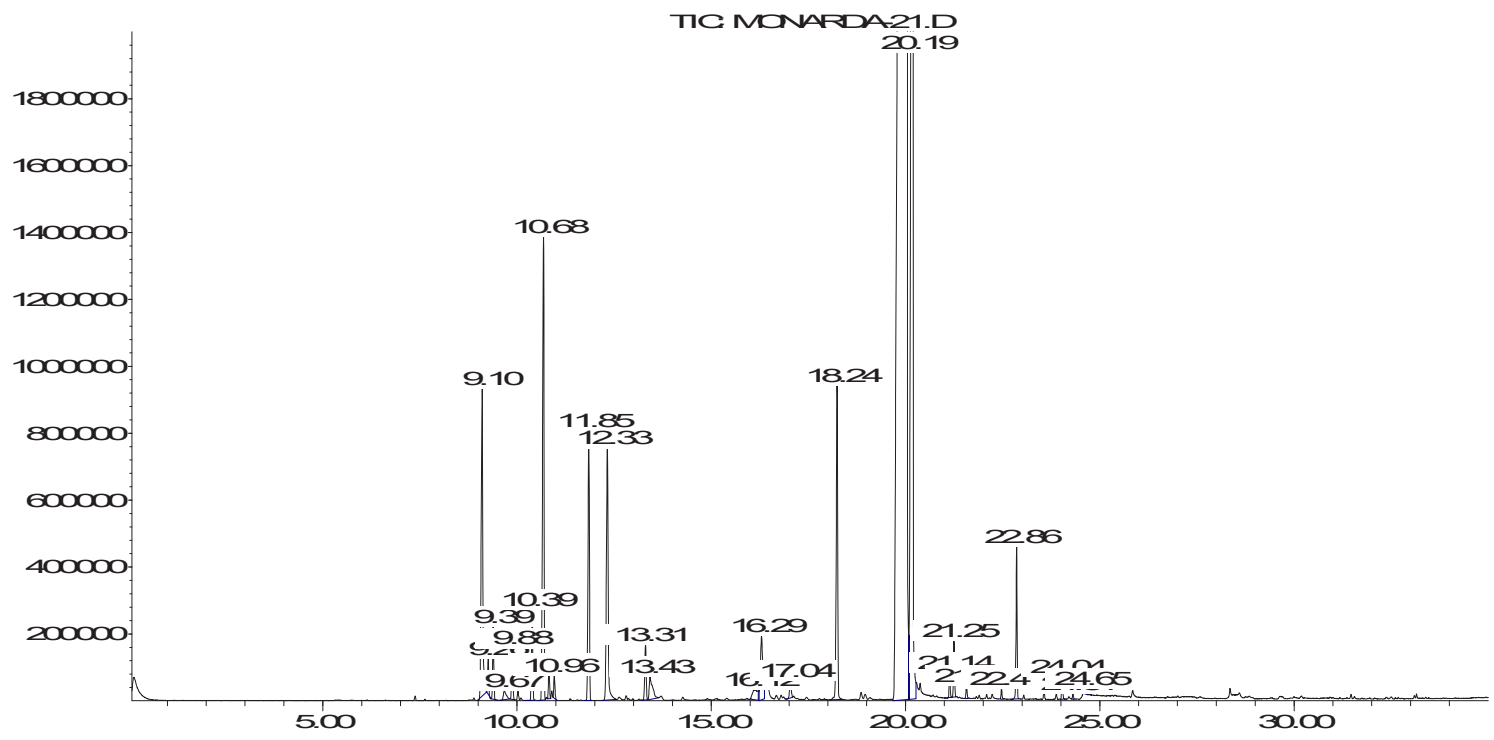

Tirre $\rightarrow$

Рис. 2. ГХ/МС хроматограма ефрірної олії M. citriodora (фраза масового цвітіння рослин).<smiles>Cc1ccc(C(C)C)c(O)c1</smiles>

Тимол<smiles>Cc1ccc(C(C)C)cc1O</smiles>

Карвакрол<smiles>Cc1ccc(C(C)C)c(C)c1O</smiles>

Метилкарвакрол<smiles>Cc1ccc(C(C)C)cc1</smiles>

п-Цимен<smiles>C=C1CC=C(C(C)C)CC1</smiles>

y-Терпінен

Рис. 3. Структурні фрормули домінуючих компонентів ефрірних олій M. citriodora.

ISSN 2312-0967. Фармацевтичний часопис. 2021. № 1 
Фітохімічні дослідження Phytochemical researches

$\%$

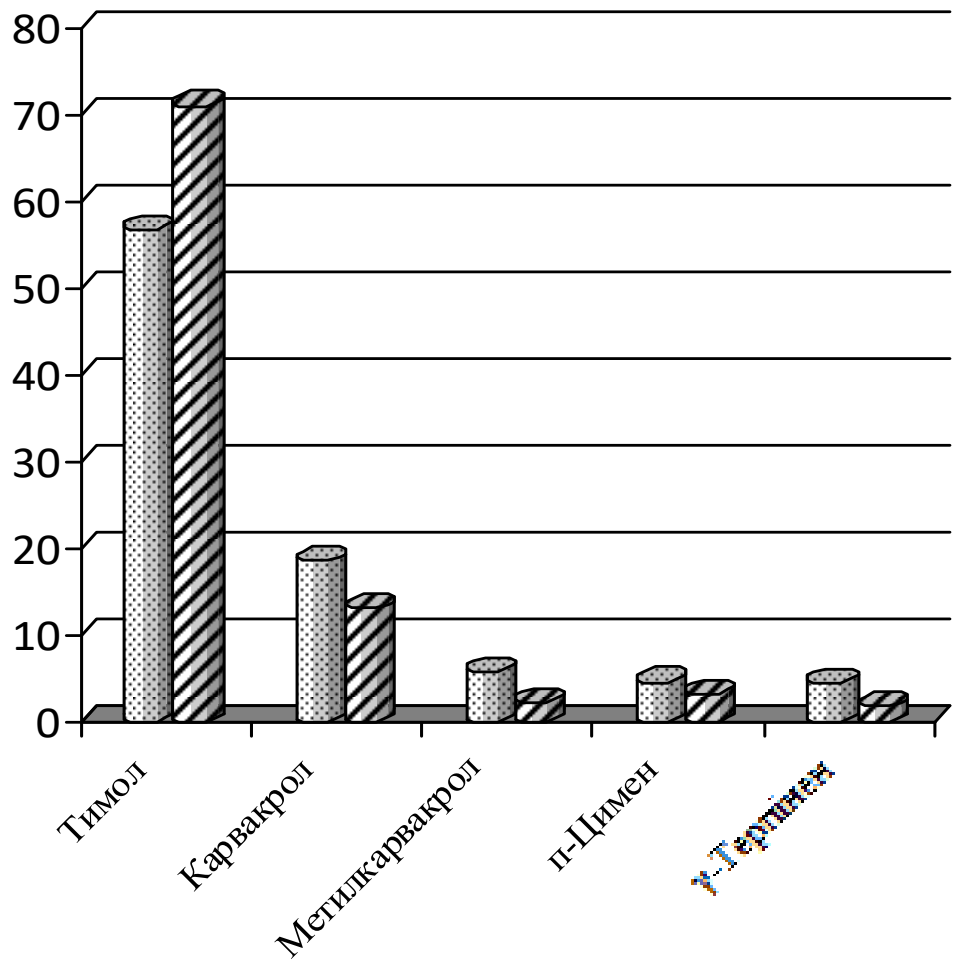

๑ Початок цвітіння

$\square$ Масове цвітіння

Рис. 4. Порівняльний аналіз вмісту основних компонентів ефрірної олії M. citriodora залежно від фрази вегетації рослин.

антимікробний ефект стосовно уропатогенних штамів Escherichia coli продемонстрували есрірні олії двох видів родини Lamiaceae: Thymus vulgaris, у складі якої домінував тимол, і Origanum vulgare, у якій переважав карвакрол. Як було визначено T. Karpiński [5], серед десятків представників родини Lamiaceae ефрірні олії видів роду Thymus найактивніше пригнічували патогенні мікроорганізми, відповідно до домінування ароматичних компонентів у їхньому складі. Ефрірна олія Thymus vulgaris, у складі якої превалювали тимол (61,9\%), п-цимен $(10,0 \%)$ і $y$-терпінен $(10,0 \%)$, виявила значний інгібуючий ефект на антибіотикорезистентні штами Staphylococcus aureus [6]. Для еорірної олії одного 3 видів роду Monarda - M. punctata, у складі якої було $75,2 \%$ тимолу, теж встановлено антимікробний есрект щодо Staphylococcus aureus [20]. Fraternale D. та співавтори [9] виявили, що ефрірна олія M. didyma, в якій було виявлено 57,3 \% тимолу, інгібувала фрітопатогенні грибки Rhizoctonia solani та Botrytis cinerea. Staphylococcus aureus i Candida albicans виявили чутливість до ефрірної олії M. fistulosa, у складі якої переважали тимол (42,01 \%) і п-цимен $(15,45 \%)[4]$.

На основі проведеного ТШХ-аналізу ефрірної олії M. citriodora (рис. 5), вилученої із сировини рослини під час ії масового цвітіння, доведено наявність тимолу $\left(R_{\mathrm{f}}=0,43\right.$; рухома фраза: толуол - етилацетат
(95:5)) як її основного аналітичного та біологічно активного маркера. Визначений хроматографрічний профріль ефрірної олії M. citriodora вітчизняної заготівлі можна використовувати для її подальшої ідентифрікації.

Як визначили різні дослідники [9, 12, 13, 21, 22], компонентний склад ефірних олій рослин залежить як від їх генетичних особливостей (підвиду, культивару, хемотипу), так і впливу різноманітних екологічних факторів, таких як: географічної широти, висоти над рівнем моря, погодних умов року, взаємовідносин із мікроорганізмами і тваринами, особливостей культивування, періоду заготівлі тощо. Lu Z. G. та співавтори [22] встановили, що переважаючими компонентами ефрірної олії M. citriodora при заготівлі сировини на північному сході Китаю були тимол (44,6 \%) і 1,8-цинеол (23,6 \%). Каріофілен (19,15 \%) був домінуючим компонентом ефрірної олії із трави цього виду, яку було заготовлено в Індії [14]. Інші індійські дослідники [15] виявили тимольний хемотип M. citriodora, оскільки тимол (82 \%) значно превалював над іншими компонентами есрірної олії: карвакролом (4,82\%), $\beta$-мірценом (3,45 \%) та ін. Тимол був також домінуючим компонентом $(66,4 \%)$ ефрірної олії M. citriodora, заготовленої в Італії [23]. Науковці відмічають наявність хемотипових відмінностей у компонентному складі ефрірних олій і в межах інших родів та видів родини Lamiaceae [24, 25].

ISSN 2312-0967. Pharmaceutical review. 2021. № 1 


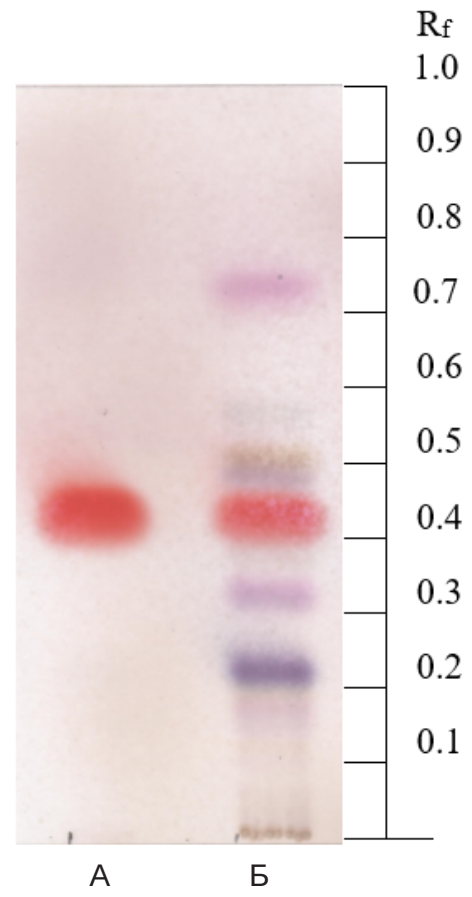

Рис. 5. ТШХ хроматограми стандартного зразка тимолу (А) та розчину есрірної олії $M$. citriodora (Б) після дериватизації анісового альдегіду розчином при денному світлі. Рухома фраза: толуол - етилацетат (95:5).

На основі узагальнення отриманих нами результатів та їх порівняння із даними наукових першоджерел було визначено, що досліджувана ефрірна олія трави M. citriodora вітчизняної заготівлі, незалежно від фрази вегетації рослини (початок чи масове цвітіння), належить до тимолово-карвакролового хемотипу.

Висновки. 1. Методом ГХ/МС вивчено компонентний склад есрірних олій сировини M. citriodora, заготовленої у дві фрази вегетації під час культивування в умовах Херсонської області: початку цвітіння та масового цвітіння. Домінуючими компонентами обох ефрірних олій були ароматичні монотерпеноїди тимол і карвакрол, сумарний вміст яких був вищим у фразу масового цвітіння рослин.
2. На основі отриманих даних ГХ/МС аналізу визначено хемотипові особливості ефрірної олії об'єкту дослідження - M. citriodora вітчизняної заготівлі, який віднесено до тимолово-карвакролового хемотипу.

3. Запропоновано застосувати ТШХ-аналіз ефрірної олії досліджуваної рослини як експрес-метод її ідентифрікації.

4. У перспективі доцільним можна вважати порівняльне вивчення біологічної активності ефрірних олій із трави M. citriodora, заготовленої у різні фрази вегетації.

Конфрлікт інтересів: відсутній.

Conflicts of interest: authors have no conflict of interest to declare.

\section{CHROMATOGRAPHIC ANALYSIS OF ESSENTIAL OILS OBTAINED FROM THE LEMON BEEBALM HERB IN THE DIFFERENT VEGETATION PHASES}

\section{I. Shanaida ${ }^{1}$,L. V. Svydenko ${ }^{2}$, N. V. Hvozdyk ${ }^{1}$, N. I. Hudz ${ }^{3}$}

I. Horbachevsky Ternopil National Medical University ${ }^{1}$ Sector of Mobilization and Conservation of Plant Resources of the Rice Institute of the NAAS Danylo Halytsky Lviv National Medical University ${ }^{3}$ shanayda@tdmu.edu.ua

The aim of the work. Chromatographic analysis of essential oils obtained from the lemon beebalm (Monarda citriodora Cerv. ex Lag, Lamiaceae Martinov family) herb in the different phases of vegetation.

Materials and Methods. The herb of $M$. citriodora was harvested in the experimental plots of Kherson region (Ukraine) during two phases of vegetation: beginning of flowering and total flowering. The essential oil was obtained by hydrodistillation. Its

ISSN 2312-0967. Фармацевтичний часопис. 2021. № 1 
component was studied by gas chromatography with mass spectrometry method (GC/MS). The thin layer chromatography (TLC) was used to obtain the "chromatographic fingerprints" of the essential oil.

Results and Discussion. The component composition of $M$. citriodora essential oils was studied by GC/MS. There were identified 28 components in the essential oil obtained from the herb during the beginning of flowering, and 27 compounds were found during the total flowering of plants. The predominant components of both essential oils were aromatic monoterpenoids thymol and carvacrol. Harvesting the $M$. citriodora raw materials during the total flowering was determined to be more promising because of a higher total content of thymol and carvacrol $(84.07 \%)$ in the essential oil compared to the beginning of flowering period (75.09\%). It is proposed to use the TLC analysis of essential oil harvested during mass flowering as an express method for its identification.

Conclusions. The component composition and specific features of the essential oils of the $M$. citriodora raw materials produced in Kherson region of Ukraine during two different phases of vegetation were revealed. The thymol-carvacrol chemotype of the investigated essential oil was determined. The study of the potential of the pharmacological activity of the investigated essential oil could be considered as a very prospective direction of future research.

Key words: Monarda citriodora; essential oil; gas chromatography; thin layer chromatography; thymol; carvacrol; chemotype.

\title{
ХРОМАТОГРАФИЧЕСКИЙ АНАЛИЗ ЭФИРНЫХ МАСЕЛ ТРАВЫ МОНАРДЫ ЛИМОННОЙ РАЗЛИЧНЫХ ФАЗ ВЕГЕТАЦИИ
}

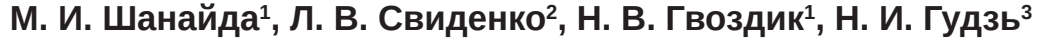 \\ Тернопольский национальный медицинский университет имени И. Я. Горбачевского МЗ Украины \\ Сектор мобилизации и сохранения растительных ресурсов Института риса $\mathrm{HAAH}^{2}$ \\ Львовский национальный медицинский университет имени Данила Галицкого ${ }^{3}$ \\ shanayda@tdmu.edu.ua
}

Цель работы. Хроматографрический анализ эфирных масел монарды лимонной (Monarda citriodora Cerv. ex Lag, семейство Lamiaceae Martinov), полученных из травы растения в разные фразы вегетации.

Материалы и методы. В качестве материала для исследований использовали траву M. citriodora, которую заготавливали на опытных участках в Херсонской обл. (Украина) во время двух фраз вегетации: начала цветения и массового цветения растений. Эфирное масло получали методом гидродистилляции. Анализ его компонентного состава проводили методом газовой хроматографии с масс-спектрометрическим детектированием (ГХ/МС). Для получения «хроматографических отпечатков» эфирного масла использовали метод тонкослойной хроматограсрии (TCX).

Результаты и обсуждение. На основании анализа ГХ/МС изучен компонентный состав эфирного масла сырья M. citriodora. В эфирном масле, полученном из травы растения во время начала его цветения, идентифицировано 28 компонентов; во время массового цветения - 27. Доминирующими компонентами обеих эфирных масел были ароматические монотерпеноиды тимол и кавракрол. Проведение заготовки сырья M. citriodora во время сразы массового цветения определено как более перспективное, учитывая более высокое суммарное содержание в эфирном масле тимола и карвакрола (84,07 \%) в этот период по сравнению с началом цветения (75,09 \%). Предложено применять ТСХ-анализ эфирного масла из травы исследуемого растения, заготовленной во время массового цветения как экспресс-метод его идентификации.

Выводы. Определены компонентный состав и специфические особенности эфирных масел сырья M. citriodora, заготовленного в Херсонской области (Украина) во время двух разных фаз вегетации, на основе чего был установлен их тимольно-карвакрольный хемотип. В перспективе определена целесообразность изучения потенциала фрармакологической активности эфирного масла исследуемого растения.

Ключевые слова: Monarda citriodora; эфрирное масло; газовая хроматография; тонкослойная хроматография; тимол; карвакрол; хемотип.

\section{Список бібліографічних посилань}

1. Bedi S., Tanuja, Vyas S.P. A handbook of aromatic and essential oil plants (cultivation, chemistry, processing and uses). Jodhpur: Agrobios, 2010. 598 p.

2. Biological activities of essential oils: from plant chemoecology to traditional healing systems. J. Sharifi-Rad,
A. Sureda, G. C. Tenore et al. Molecules. 2017. N 22, 70.

3. Воробець Н. М., Рівіс О. Ю. Актуальність та перспективи використання лікарських рослин для лікування кандидозу ротової порожнини. Вісник

ISSN 2312-0967. Pharmaceutical review. 2021. № 1 
проблем біології і медицини. 2017. Вип. 1 (135). C. 22-32.

4. Шанайда М. І., Покришко О. В. Антимікробна активність ефірних олій культивованих представників родини Lamiaceae Juss. Annals of Mechnikov Institute. 2014. № 4. P. 66-69.

5. Karpiński T. M. Essential oils of Lamiaceae family plants as antifungals. Biomolecules. 2020. Vol. 10(1), 103.

6. Antimicrobial activity of five essential oils from Lamiaceae against multidrug-resistant Staphylococcus aureus. B. Kot, K. Wierzchowska, M. Piechota et al. Nat. Prod. Res. 2019. Vol. 33 (24). P. 3587-3591.

7. Lee J. H., Kim Y.G., Lee J. Carvacrol-rich oregano oil and thymol-rich thyme red oil inhibit biofilm formation and the virulence of uropathogenic Escherichia coli. J. Appl. Microbiol. 2017. Vol. 123 (6). P. 1420-1428.

8. Antioxidant activity of essential oils obtained from aerial part of some Lamiaceae species M. Shanaida, N. Hudz, K. Korzeniowska, P. Wieczorek. International Journal of Green Pharmacy. 2018. Vol. 12 (3). P. 200-204.

9. Chemical composition, antifungal and in vitro antioxidant properties of Monarda didyma L. essential oil. D. Fraternale, L. Giamperi, A. Bucchini et al. J. Ess. Oil Res. 2006. Vol. 18. P. 581-585.

10. Державна Фармакопея України: в 3 т. / ДП «Український науково-експертний фрармакопейний центр якості лікарських засобів». 2-е вид. Харків : ДП «Український науково-експертний фрармакопейний центр якості лікарських засобів». 2014. Т. 3. 732 с.

11. Вронська Л. В. Застосування тонкошарової хроматограсрії для ідентифікації трави меліси лікарської. Фармацевтичний часопис. 2011. № 4. С. 64-67.

12. Высочина Г. И. Род Monarda L. (Lamiaceae): химический состав, биологическая активность и практическое применение (Обзор). Химия в интересах устойчивого развития. 2020. Vol. 28 (2). C. 107-123.

13. Федотов С. В. Эфирные масла монард видов Monarda fistulosa L., Monarda didyma L., Monarda citriodora Cervantes ex Lag., их хемотипы и биологическая активность. Сборник научных трудов ГНБС. 2015. T. 141.URL: //www.real-aroma.ru/period_izdania/ sbornik GNBS/monarda.htm

14. Nanoencapsulated Monarda citriodora Cerv. ex Lag. essential oil as potential antifungal and antiaflatoxigenic agent against deterioration of stored functional foods. Deepika, A. Singh, A. K. Chaudhar et al. J. Food Sci. Technol. 2020. Vol. 57 (8). P. 2863-2876.

\section{References}

1. Bedi S, Tanuja, Vyas SP. A handbook of aromatic and essential oil plants (cultivation, chemistry, processing and uses). Jodhpur: Agrobios, 2010.

2. Sharifi-Rad J, Sureda A, Tenore GC, Daglia M, SharifiRad M, Marco Valussi $M$ et al. Biological activities of essential oils: from plant chemoecology to traditional healing systems. Molecules. 2017;22: 70.

3. Vorobets $\mathrm{N}$, Rivis $\mathrm{O}$. Actuality and perspectives of using medicinal plants for the treatment of oral candidia-
15. Disruption of the PI3K/AKT/mTOR signaling cascade and induction of apoptosis in HL-60 cells by an essential oil from Monarda citriodora. A. S. Pathania, S. K. Guru, M. K. Verma et al. Food and Chemical Toxicology. 2013. Vol. 62. P. 246-254.

16. Pharmacological properties and molecular mechanisms of thymol: prospects for its therapeutic potential and pharmaceutical development. M. F. Nagoor Meeran, H. Javed, H. Al Taee et al. Front. Pharmacol. 2017. Vol. 8, 380.

17. Phytochemical evaluation of tinctures and essential oil obtained from Satureja montana herb. N. Hudz, E. Makowicz, M. Shanaida et al. Molecules. 2020. Vol. 25 (20), 4763.

18. Carvacrol and thymol: strong antimicrobial agents against resistant isolates. M. Y. Memar, P. Raei, N. Alizadeh et al. Reviews in Medical Microbiology. 2017. Vol. 28 (2). P. 63-68.

19. Essential oils from Monarda fistulosa: chemical composition and activation of transient receptor potential A1 (TRPA1) channels. M. Ghosh, I. A. Schepetkin, G. Özek et al. Molecules. 2020. Vol. 25(21), 4873.

20. Antibacterial activity and mechanism of action of Monarda punctata essential oil and its main components against common bacterial pathogens in respiratory tract. H. Li, T. Yang, F.-Y. Li et al. Int. J. Clin. Exp. Pathol. 2014. Vol. 7 (11). P. 7389-7398.

21. Morphological and phytochemical screening of some Thymus ecotypes (Thymus spp.) native to Iran in order to select elite genotypes. S. Mohammadi, L. Tabrizi, M. Shokrpour et al. Journal of Applied Botany and Food Quality. 2020. Vol. 93. P. 186-196.

22. Lu Z.G., Li X.H., Li W. Chemical composition of antibacterial activity of essential oil from Monarda citriodora flowers. Advanced Materials Research. 2011. Vol. 183. P. 920-923.

23. Monarda citriodora hydrolate vs essential oil comparison in several anti-microbial applications. M. Di Vito, G. Bellardi, F. Mondello et al. Industrial Crops and Products. 2019. Vol. 128. P. 206-212.

24. Phytochemistry, chemotaxonomy, ethnopharmacology, and nutraceutics of Lamiaceae. C. Frezza, A. Venditti, M. Serafini, A. Bianco. Studies in Natural Products Chemistry. 2019. Vol. 2. P. 125-178.

25. The phytochemical and chemotaxonomic study of Salvia spp. growing in Ukraine. O. Koshovyi, A. Raal, A. Kovaleva et al. J. Appl. Biol. Biotech. 2020. Vol. 8 (3). P. 29-36.

sis. Visnyk problem biolohii i medytsyny. 2017;1(135): 22-32. Ukrainian.

4. Shanayda MI, Pokryshko OV. Antimicrobial activity of essential oils of plants belonging to Lamiaceae Juss. family. Annals of Mechnikov Institute. 2014;4: 66-9. Ukrainian.

5. Karpiński TM. Essential oils of Lamiaceae family plants as antifungals. Biomolecules. 2020;10(1): 103.

6. Kot B, Wierzchowska K, Piechota M, Czerniewicz $P$, Chrzanowski G. Antimicrobial activity of five essential

ISSN 2312-0967. Фармацевтичний часопис. 2021. № 1 
oils from Lamiaceae against multidrug-resistant Staphylococcus aureus. Nat. Prod. Res. 2019;33(24): 3587-91.

7. Lee JH, Kim YG, Lee J. Carvacrol-rich oregano oil and thymol-rich thyme red oil inhibit biofilm formation and the virulence of uropathogenic Escherichia coli. J. Appl. Microbiol. 2017;123(6): 1420-8.

8. Shanaida M, Hudz N, Korzeniowska K, Wieczorek PP Antioxidant activity of essential oils obtained from aerial part of some Lamiaceae species International Journal of Green Pharmacy. 2018;12(3): 200-4.

9. Fraternale D, Giamperi L, Bucchini A, Ricci D, Epifano F, Burini G, Curini M. Chemical composition, antifungal and in vitro antioxidant properties of Monarda didyma L. essential oil. J Ess Oil Res. 2006;18: 581-5.

10. The State Pharmacopoeia of Ukraine: Ukrainian Scientific Pharmacopoeia Center of Quality of Medicinal Products. Ed.2. [Державна Фармакопея України: ДП «Український науково-експертний фрармакопейний центр якості лікарських засобів». 2-е вид. Харків: ДП «Український науково-експертний фрармакопейний центр якості лікарських засобів»] Kharkiv: Ukrainian Scientific Pharmacopoeia Center of Quality of Medicinal Products. 2014. Ukrainian.

11. Vronska LV. Application of thin layer chromatography method for lemon balm herb identification. Farm chasop. 2011;4: 64-7. Ukrainian.

12. Vysochina, G.I. Genus Monarda (Lamiaceae): chemical composition, biological activity and practical application (a review). Chemistry in the Interest of Sustainable Development. 2020; 28(2): 105-20. Russian.

13. Fedotov SV. Essential oils of Monarda fistulosa L., Monarda didyma L., Monarda citriodora Cervantes ex Lag., their chemotypes and biological. Sbornik nauchnych trudov SNBG. 2015; 141. Available from: http:// www.real-aroma.ru/period_izdania/sbornik_GNBS/monarda.htm Russian.

14. Deepika, Singh A, Chaudhar AK, Das S, Dubey NK. Nanoencapsulated Monarda citriodora Cerv. ex Lag. essential oil as potential antifungal and antiaflatoxigenic agent against deterioration of stored functional foods. J Food Sci Technol. 2020;57(8): 2863-76.

15. Pathania AS, Guru SK, Verma MK, Sharma G, AbdulIah ST, Fayaz Malik F et al. Disruption of the PI3K/AKT/ mTOR signaling cascade and induction of apoptosis in HL-60 cells by an essential oil from Monarda citriodora. Food and chemical toxicology. 2013;62: 246-54.
16. Nagoor Meeran MF, Javed $\mathrm{H}$, Al Taee $\mathrm{H}$, Azimullah S, Ojha SK. Pharmacological properties and molecular mechanisms of thymol: prospects for its therapeutic potential and pharmaceutical development. Front Pharmacol. 2017;8: 380.

17. Hudz N, Makowicz E, Shanaida M, Białoń M, Jasicka-Misiak I, Yezerska O, Svydenko L, Wieczorek PP. Phytochemical evaluation of tinctures and essential oil obtained from Satureja montana herb. Molecules. 2020;25(20): 4763.

18. Memar MY, Raei P, Alizadeh N, Aghdam MA, Kafil HS. Carvacrol and thymol: strong antimicrobial agents against resistant isolates. Reviews in Medical Microbiology. 2017;28(2): 63-8.

19. Ghosh M, Schepetkin IA, Özek G, Özek T, Khlebnikov Al, Damron DS, Quinn MT. Essential oils from Monarda fistulosa: chemical composition and activation of transient receptor potential A1 (TRPA1) channels. Molecules. 2020;25(21): 4873.

20. Li H, Yang T, Li F-Y, Yao Y, Sun Z-M. Antibacterial activity and mechanism of action of Monarda punctata essential oil and its main components against common bacterial pathogens in respiratory tract. Int J Clin Exp Pathol. 2014;7(11); 7389-98.

21. Mohammadi S, Tabrizi L, Shokrpour M, Hadian J, Schulz H, Riewe D. Morphological and phytochemical screening of some Thymus ecotypes (Thymus spp.) native to Iran in order to select elite genotypes. Journal of Applied Botany and Food Quality. 2020;93: 186-96.

22. Lu ZG, Li XH, Li W. Chemical composition of antibacterial activity of essential oil from Monarda citriodora flowers. Advanced Materials Research. 2011;183: 9203.

23. Di Vito M, Bellardi G, Mondello F, Modesto M, Michelozzi M, Bugli F et al. Monarda citriodora hydrolate vs essential oil comparison in several anti-microbial applications. Industrial Crops and Products. 2019;128: 206-12.

24. Frezza C, Venditti A, Serafini M, Bianco A. Phytochemistry, chemotaxonomy, ethnopharmacology, and nutraceutics of Lamiaceae. Studies in Natural Products Chemistry. 2019;2: 125-78.

25. Koshovyi O, Raal A, Kovaleva A, Myha M, Ilina T, Borodina N, Komissarenko A. The phytochemical and chemotaxonomic study of Salvia spp. growing in Ukraine. J Appl Biol Biotech. 2020;8(3): 29-36.

\section{Відомості про авторів}

Шанайда М. І. - канд. біол. наук, доцент кафедри фрармакогнозії з медичною ботанікою, Тернопільський національний медичний університет імені І. Я. Горбачевського МО3 України, Тернопіль, Україна. E-mail: shanayda@tdmu.edu.ua, ORCID 0000-0003-1070-6739

Свиденко Л. В. - канд. біол. наук, старший науковий співробітник сектору мобілізації та збереження рослинних ресурсів, Інститут рису НАAН України. E-mail: svid65@ukr.net, ORCID 0000-0002-4043-9240

Гвоздик Н. В. - студентка 5 курсу фрармацевтичного фракультету, Тернопільський національний медичний університет імені І. Я. Горбачевського МОЗ України, Тернопіль, Україна. E-mail: gvozdyk_nava@tdmu.edu.ua.

Гудзь Н. І. - канд. фрармац. наук, доцент кафедри технології ліків і біофармації, Львівський національний медичний університет імені Данила Галицького. E-mail: natali_gudz@ukr.net, ORCID 0000-0002-2240-0852. 


\section{Information about the authors}

Shanaida M. I. - PhD (Biology), Associate Professor of the Department of Pharmacognosy and Medical Botany, I. Horbachevsky Ternopil National Medical University, Ukraine. E-mail: shanayda@tdmu.edu.ua, ORCID 0000-0003-10706739

Svydenko L. V. - PhD (Biology), Senior Researcher of the Sector of Mobilization and Conservation of Plant Resources of the Rice Institute of the NAAS, Ukraine. E-mail: svid65@ukr.net, ORCID 0000-0002-4043-9240

Hvozdyk N. V. - fifth-year student of Pharmaceutical Faculty, I. Horbachevsky Ternopil National Medical University, Ukraine. E-mail: gvozdyk_nava@tdmu.edu.ua.

Hudz N. I. - PhD (Pharmacy), Associate Professor of the Department of Drug Technology and Biopharmacy, Danylo Halytsky Lviv National Medical University, Ukraine. E-mail: natali_gudz@ukr.net, ORCID 0000-0002-2240-0852 